\title{
The Effects of Corn Cobs in Feed
}

\author{
Daniel Mierliță - Gheorghe Sălăjan - Bogdan \\ Georgescu - Antonia Odagiu \\ University of Agricultural Sciences and Veterinary Medicine,
}

Cluj-Napoca

\section{SUMMARY}

This study is part of a larger research work that aims to establish the usefulness of corn cobs, a low cost dietary resource, in the growth of ruminants. Corn cobs are found in large amounts in our country ( $8.2 \mathrm{mil}$. tons/year). Increasing the quantity of corn cobs to $50 \%$ of the diet in lambs resulted in a decrease by $14.57 \%$ in the concentrate intake that is needed to obtain one-kg weight increase. In addition, the diet costs were reduced by $16.33 \%$ (Mierliță, 1999). Increasing the quantity of corn cobs to 20-50\% of the diet also resulted in multiplication of bacteria from genus Ruminococcus, that are known to represent about $70-80 \%$ of the bacteria population in the rumen. In addition, an increased multiplication rate of large protozoas (i.e. Epidinium, Isotrichia, Diplodinium etc) was observed. This explains the high conversion rate of piruvic acid, a carbohydrate fermentation product, into acetic acid, whereas conversion of piruvic acid into propionic acid decreases. In addition, feed intake and the quantity of digested and absorbed fibers increased by $8.46 \%$ and 35.09\%, respectively. Thus, a reduction in dietary concentrates needed as nutrient supplies was achieved.

\section{INTRODUCTION}

Ruminal roughage digestion is a particularity that allows for the use of forage resources that are not accessible to other species.

For diets containing $27 \%-81 \%$ dry mater roughage content, we observed an increase of cellulose digestion percentage from $51 \%$ to $71 \%$, and the microbial nitrogen synthesized in the rumen was $32 \mathrm{~g} \mathrm{~N} / \mathrm{kg}$ carbohydrates fermented in the rumen (Tamminga, 1987).

The different nitrogen quantities from the diet directly influence the allozyme activity (glutamate dehidrogenase) of ruminal bacteria and at the same time the ruminal metabolism and the digestibility of nutritive substances (Houtert et al., 1993).

In this experiment the lambs were feed with four diets at different proportions of corn cobs and various protein ratios, in order to determine how the structure and protein ratio of feed is reflected on ruminal microecosystem, metabolism and diet digestibility.

\section{MATERIAL AND METHOD}

The present study was carried out at the University of Agricultural Sciences and Veterinary Medicine Cluj-Napoca, between 12. 04. - 01. 10. 1998.

The composition and the nutritional value of diets is presented in Table 1. Note that the corn cob proportion on the dietary structure ( $\%$ of weight) gradually increased from $20 \%$ for group 1 (control) to $50 \%$ for group 4 , while the calorie/protein ratio decreased from 2.50 to 1.50 (Table 1 ).
Table 1: The composition and nutritional value of feed

\begin{tabular}{|l|r|r|r|r|}
\hline \multirow{2}{*}{ Issue } & \multicolumn{4}{|c|}{ Experimental groups } \\
\cline { 2 - 5 } & $\mathbf{G}_{\mathbf{1}}(\mathbf{C})$ & \multicolumn{1}{|c|}{$\mathbf{G}_{\mathbf{2}}$} & \multicolumn{1}{c|}{$\mathbf{G}_{\mathbf{3}}$} & \multicolumn{1}{c|}{$\mathbf{G}_{\mathbf{4}}$} \\
\hline a) Feed composition (\% of weight) \\
\hline Corn cobs & 20.00 & 30.00 & 40.00 & 50.00 \\
\hline Concentrate mixture & 80.00 & 70.00 & 60.00 & 50.00 \\
\hline TOTAL & 100.00 & 100.00 & 100.00 & 100.00 \\
\hline b) Nutritional characteristics \\
\hline N.U./kg forage & 0.93 & 0.84 & 0.74 & 0.65 \\
\hline C.P. (\%) & 16.00 & 16.00 & 16.00 & 16.00 \\
\hline Calorie/protein ratio & 2.50 & 2.21 & 1.84 & 1.50 \\
\hline Crude fiber (\%) & 15.47 & 19.57 & 24.28 & 28.36 \\
\hline
\end{tabular}

$\mathrm{G}_{1}(\mathrm{C})=$ control group

N.U. $=$ feed unit-oats; 1 N.U. $=1416 \mathrm{kcal}$ net energy

C.P. $=$ crude protein

The feed nutritional value was calculated based on the crude chemical analysis of forages that were included in diet composition.

Lambs $(21.5 \pm 1.4 \mathrm{~kg})(\mathrm{n}=5)$ were used which had been fed specific diets for 16 days. After this period, prelevated ruminal liquid samples and digestibility tests were performed. The ruminal liquid samples were prelevated with a buco-esophagian tube, at 3-4 hours after forage administration, and immediately examined in order to determine $\mathrm{pH}$, the total number of bacteria and protozoa, and also in order to identify the main species in the ruminal biotope. Simultaneously ruminal liquid samples were obtained in order to establish the percentual composition of volatile fatty acids (VFA). $\mathrm{pH}$ was established using the $\mathrm{pH}$-meter, type MV 85, calibrated with tampon solutions for the interval $\mathrm{pH}$ $=3.5-10.5$. The bacteria species were identified using the method described by Hungate (1969), and the bacterial population cultures were counted using a counting chamber, following the technique described by Bryant (1961). Predominant protozoa species were determined and counted using a microscope and the haemocytometric method, following the technique described by Dehorty and Cole (1971). The VFA determination was performed using a Perkin Elmer gaschromatograph, their concentration being presented as a percentage of the total VFA identified.

The digestibility test was performed over 8 days, in digestibility cages especially built for this purpose; faeces prelevation was done three times a day. The feed intake and excreta crude chemical composition were determined using the Wendee method.

The results were statistically processed using the test ,t”. 


\section{RESULTS AND DISCUSSION}

The results concerning the influence of feed composition on ruminal $\mathrm{pH}$ and the micro ecosystem are presented in Table 2.

Table 2: The influence of feed structure on ruminal microbial micro ecosystem

\begin{tabular}{|c|c|c|c|c|}
\hline \multirow{2}{*}{ Issue } & \multicolumn{4}{|c|}{ Experimental groups } \\
\hline & $\mathrm{G}_{1}(\mathrm{C})$ & $\mathbf{G}_{2}$ & $\mathbf{G}_{3}$ & $\mathbf{G}_{\mathbf{4}}$ \\
\hline Ruminal pH & 6.30 & 6.45 & 6.55 & 6.90 \\
\hline \multicolumn{5}{|l|}{ a) Ruminal bacteria } \\
\hline $\begin{array}{l}\text { Total number }\left(\times 10^{8} / \mathrm{ml}\right) \text { from } \\
\text { which }(\% \text { from total }) \text { : }\end{array}$ & 76.41 & 73.14 & 55.90 & 42.37 \\
\hline Ruminococus flavefaciens & 30.42 & 33.64 & 36.62 & 40.32 \\
\hline Ruminococus albus & 31.74 & 34.81 & 36.37 & 38.87 \\
\hline Bacteroides ruminicola & 12.73 & 10.22 & 7.12 & 3.90 \\
\hline Selenomonas ruminantium & 16.55 & 13.07 & 10.85 & 6.36 \\
\hline Clostridium lochheadi & 2.23 & 2.92 & 4.56 & 6.23 \\
\hline Clostridium longisporum & 0.42 & 0.89 & 1.27 & 2.11 \\
\hline Bacteroides amylophylus & 5.91 & 4.45 & 3.21 & 2.21 \\
\hline \multicolumn{5}{|l|}{ b) Ruminal protozoa } \\
\hline $\begin{array}{l}\text { Total number }\left(\times 10^{6} / \mathrm{ml}\right) \text { from } \\
\text { which ( } \% \text { from total): }\end{array}$ & 1.334 & 1.431 & 1.551 & 1.456 \\
\hline Entodinium & 91.21 & 84.50 & 77.25 & 65.31 \\
\hline Epidinium & 4.20 & 7.71 & 12.10 & 20.30 \\
\hline Diplodinium & 2.69 & 4.40 & 5.85 & 7.89 \\
\hline Isotrichia & 1.10 & 2.00 & 2.80 & 5.40 \\
\hline Ostracodinium & 0.76 & 1.30 & 1.80 & 0.80 \\
\hline Polyplastron multiresticulatum & 0.04 & 0.09 & 0.20 & 0.30 \\
\hline
\end{tabular}

From the data presented in this table we observe a gradual increase of ruminal $\mathrm{pH}$ from 6.30 in lambs from group 1 (control) ( $20 \%$ corn cobs in feed) to 6.90 in lambs from group 4 (50\% corn cobs in feed), due to an enhancement of saliva secretion simultaneously with the corn cobs proportion in diet, that led to a higher saliva secretion and the buffering of ruminal acidity.

The total number of bacteria in ruminal juice decreased by $44.5 \%$ during the same period with the increase of the proportion of corn cobs in the feed structure, because it is well known that over $2 / 3$ of the total number of bacteria are fixed on forage particles, especially on those rich in cellulose (Crista, 1998). Thus, the number of free bacteria from ruminal juice was higher in lambs fed with diets rich in concentrates (Table 2).

From the total number of identified bacteria, the increase of the proportion of corn cobs in feed composition (from $20 \%$ to $50 \%$ ) increased simultaneously with the proportion of cellulolitical bacteria to $27.40 \%$ (from these are predominant the species Ruminococus flavefaciens and Ruminococus albus) in disadvantage of amilolitical bacteria, that decreased by $64.95 \%$. We have to mention that the amilolitical bacteria are smaller and have a higher multiplication velocity than cellulolitical bacteria (Crista, 1998).

Concerning the total number of protozoa we found that they had a maximum level of $1.551 \mathrm{x}$ $10^{6} / \mathrm{ml}$ ruminal liquid when corn cobs compozed $40 \%$ of diet weight. Of the total number of protozoa, at the same time as the increase of the proportion of corn cobs in feed composition, the proportion of the species with great dimensions (Epidinium, Isitriche, Diplodinium etc) increased, and the prevalence of those with small dimensions (Entodinium) decreased.

These alterations in the ruminal microecosystem were reflected in ruminal metabolism, and fermentation final products, respectively (Table 3). Thus, the enhancement of celullolitical bacteria presence occurring simultaneously to an increase in the proportion of corn cob in feed composition led to an increase in the acetate proportion from the total identified VFA, and to a disadvantage of propionate. The role of Ruminococus genus in cellulose degradation and in acetic fermentation are well known. The role of Bacteriodes and Selenomonas genus in simple carbohydrate degradation and in propionic fermentation, respectively, also are well known. Bacteroides genus ferments the carbohydrates to succinate, and Selenomona genus transforms the succinate in propionate by decarboxilation. The correlation between propionate from ruminal juice and the quantity of concentrate forages from diet is the result of Bacteroides and Selenomonas genus activity (Jentsch and Wittenburg, 1995; Jouany, 1994).

Table 3: Percentual composition of VFA from ruminal juice

\begin{tabular}{|l|r|r|r|r|}
\hline \multicolumn{1}{|c|}{ Volatile fatty acid } & \multicolumn{1}{c|}{$\mathbf{G}_{\mathbf{1}}(\mathbf{C})$} & \multicolumn{1}{c|}{$\mathbf{G}_{\mathbf{2}}$} & \multicolumn{1}{c|}{$\mathbf{G}_{\mathbf{3}}$} & \multicolumn{1}{c|}{$\mathbf{G}_{\mathbf{4}}$} \\
\hline Acetate & $48.90 \pm 0.33$ & $52.94 \pm 0.42^{*}$ & $57.97 \pm 0.22^{* *}$ & $62.23 \pm 0.37^{* *}$ \\
\hline Propionate & $31.30 \pm 0.21$ & $27.92 \pm 0.29^{*}$ & $23.74 \pm 0.15^{* *}$ & $20.61 \pm 0.50^{* * *}$ \\
\hline Butirate - total & 12.19 & 11.86 & 11.59 & 10.87 \\
\hline Izo - butirate & $1.52 \pm 0.10$ & $1.57 \pm 0.04$ & $1.61 \pm 0.02$ & $1.58 \pm 0.07$ \\
\hline $\mathrm{n}$ - butirate & $10.67 \pm 0.31$ & $10.29 \pm 1.08$ & $9.98 \pm 0.24$ & $9.29 \pm 0.33^{*}$ \\
\hline Valerianate - total & 7.61 & 7.28 & 6.70 & 3.29 \\
\hline Izo - valerianate & $3.34 \pm 0.06$ & $3.32 \pm 0.24$ & $3.28 \pm 0.06$ & $3.06 \pm 0.14^{* *}$ \\
\hline $\mathrm{n}-$ valerianate & $4.27 \pm 0.12$ & $3.96 \pm 0.47$ & $3.42 \pm 0.07^{*}$ & $3.02: 1^{* * *}$ \\
\hline Acetate:propionate & $1.56: 1$ & $1.90: 1^{*}$ & $2.44: 1^{* *}$ & \\
\hline
\end{tabular}

$* \mathrm{p}<0,05 ; * * \mathrm{p}<0,01 ; * * * \mathrm{p}<0,001$ 
The increase of the quantity of corn cob in diet led to an increase of the acetate and propionate ratio. This is not favorable for meat production.

In order to determine the apparent digestibility of nutritive substances it the feed intake was used the experiment with one control period. The excreta of nutritive substances was also determined. The digestibility coefficients were calculated. The feed intake and excreta and also their crude chemical composition were determined (Table 4, 5, 6).

\section{Table 4: The variation of feed intake and excreta}

\begin{tabular}{|c|c|c|c|c|c|}
\hline Issue & Unit & $\mathrm{G}_{1}(\mathrm{C})$ & $\mathbf{G}_{2}$ & $\mathbf{G}_{3}$ & $\mathbf{G}_{4}$ \\
\hline \multirow[t]{2}{*}{ Feed intake of unique forages mixture } & $\mathrm{g}$ & 12972 & 13204 & 13647 & 14070 \\
\hline & $\%$ & 100.00 & 101.78 & 105.20 & 108.46 \\
\hline \multirow[t]{2}{*}{ Excreta } & $\mathrm{g}$ & 5799 & 6541 & 7282 & 8674 \\
\hline & $\%$ & 100.00 & 112.80 & 125.57 & 149.58 \\
\hline
\end{tabular}

Table 5: The crude chemical composition of unique forages mixtures (feed intake) (\% of D. M.)

\begin{tabular}{|l|r|r|r|r|r|r|}
\hline \multicolumn{1}{|c|}{ Group } & \multicolumn{1}{c|}{ D. M. \% } & Crude protein & Crude fat & Crude fiber & $\begin{array}{c}\text { Non nitrogenous } \\
\text { substances }\end{array}$ & Crude ash \\
\hline $\mathrm{G}_{1}(\mathrm{C})$ & 88.40 & 17.87 & 3.03 & 15.74 & 59.42 & 5.21 \\
\hline $\mathrm{G}_{2}$ & 87.61 & 17.95 & 2.98 & 19.57 & 23.22 & 5.25 \\
\hline $\mathrm{G}_{3}$ & 88.46 & 18.18 & 3.07 & 27.61 & 51.16 & 46.64 \\
\hline $\mathrm{G}_{4}$ & 88.23 & 18.09 & 3.12 & 4.37 \\
\hline
\end{tabular}

Table 6: The crude chemical composition of faeces (excreta) (\% of D. M.)

\begin{tabular}{|l|r|r|r|r|r|r|}
\hline \multicolumn{1}{|c|}{ Group } & \multicolumn{1}{c|}{ D. M. \% } & Crude protein & Crude fat & Crude fiber & $\begin{array}{c}\text { Non nitrogenous } \\
\text { substances }\end{array}$ & Crude ash \\
\hline $\mathrm{G}_{1}(\mathrm{C})$ & 46.23 & 16.18 & 4.25 & 27.15 & 43.15 & 9.25 \\
\hline $\mathrm{G}_{2}$ & 46.52 & 15.26 & 3.90 & 34.05 & 38.02 & 3.77 \\
\hline $\mathrm{G}_{3}$ & 47.07 & 13.93 & 3.72 & 41.04 & 8.41 \\
\hline $\mathrm{G}_{4}$ & 47.26 & 12.13 & 3.38 & 46.98 & 29.77 & \\
\hline
\end{tabular}

Simultaneously with the increase of the proportion of the corn cobs in diet composition, feed ingest gradually increased to $8.46 \%$.

The apparent digestibility of nutritive substances of the experimental diets presented in Table 7 shows that the increase of the proportion of corn cob in feed structure led to decrease of digestibility coefficients, due to the decrease of crude fiber digestibility. The absolute quantity of digested and absorbed fiber increased to $35.09 \%$ due to a higher feed ingest. The feed digestibility decreased simultaneously with the increase of the proportion of corn cob in its structure.

Table 7: The influence of feed composition on digestibility of nutritive substances

\begin{tabular}{|c|c|c|c|c|c|c|}
\hline Experimental group & D. M. & Crude protein & Crude fat & Crude fiber & $\begin{array}{l}\text { Non nitrogenous } \\
\text { substances }\end{array}$ & Crude ash \\
\hline \multicolumn{7}{|c|}{ a) Coefficients of apparent digestibility (\%) } \\
\hline $\mathrm{G}_{1}(\mathrm{C})$ & 76.62 & 78.81 & 67.14 & 58.96 & 83.02 & 48.65 \\
\hline $\mathrm{G}_{2}$ & 73.69 & 78.12 & 66.37 & 52.26 & 82.31 & 46.95 \\
\hline $\mathrm{G}_{3}$ & 71.60 & 78.63 & 60.65 & 47.73 & 82.08 & 46.23 \\
\hline $\mathrm{G}_{4}$ & 66.98 & 78.42 & 56.07 & 41.22 & 79.45 & 45.18 \\
\hline \multicolumn{7}{|c|}{ b) The absolute quantity of digested nutritive substances (g) } \\
\hline $\mathrm{G}_{1}(\mathrm{C})$ & 8786 & 1615 & 233 & 1046 & 5657 & 235 \\
\hline $\mathrm{G}_{2}$ & 8525 & 1622 & 229 & 1183 & 5260 & 231 \\
\hline$\overline{\mathrm{G}_{3}}$ & 8602 & 1726 & 225 & 1338 & 5069 & 244 \\
\hline$\overline{\mathrm{G}_{4}}$ & 8315 & 1761 & 217 & 1413 & 4670 & 254 \\
\hline
\end{tabular}

\section{CONCLUSIONS}

The increase of the proportion of corn cobs in the composition of sheep diets leads to:

1. The increase of ruminal $\mathrm{pH}$, which is favorable for the development of acetic bacteria and large protozoa (Epidinium, Isotrichia, Diplodinium etc).

2. The increase of the presence of Ruminococus genus in disadvantage of Bacteroides and Selenomonas genus determined the transformation of piruvate (resulted from 
carbohydrates fermentation) mainly in acetate. The maximum concentration of protozoa $/ \mathrm{ml}$ ruminal liquid was recorded for the proportion of $40 \%$ corn cobs in diet structure.

3. The decrease of the dry mater digestibility is especially due to the decrease of digestibility coefficients of crude fiber, but the quantity of digested and absorbed absolute cellulose increased to $35.09 \%$, as consequence of feed ingest.

\section{REFERENCES}

Bryant, M. P. (1961): Physiology of digestion and metabolism in the ruminants. Oriel-Press, New-York

Crista, N. (1998): Digestia, metabolismul şi producțiile la rumegătoare. Ed. Ceres, Bucureşti

Dehorty, B.-Cole, D. J. (1971): Effects of nitrogen supplementation regime on microbial numbers and activity in the rumen of sheep. J. Anim. Sci., 69. 3. 1279-1289.

Houtert, M.-Van, F. J.-Nolan, J. V.-Leng, R. A. (1993): Protein, acetate, and propionate for roughage-fed lambs. Animal Production, 56. 3. 369-379.

Hungate, E. R. (1969): The rumen and its microbes. Academic Press, New York, London

Jentsch, Y.-Wittenburg, H. (1995): Comparative studies of the parameters of rumen fermentation and the digestibility of feed rations in cattle and sheep. 1. Parameters of rumen fermentation. Journal of Physiology, London, 437-444.

Jouany, J. P. (1994): Les fermentations dans le rumen et leur optimisation. INRA Paris, Production Animales, 7. 3. 207 225.

Mierlita, D. (1999): Cercetari privind optimizarea amstecurilr de nutreturi unice destinate îngrasarii tineretului ovin. Teza de doctorat. USAMV, Cluj-Napoca

Tamminga, S. (1987): Relation between different carbohydrates and microbial synthesis of protein. Proceedings of the symposium FAO, Geneva 